by Orange Hill Girls' Grammar School, Edgware. This showed stages in the preparation of diagrams for a film strip illustrating the life-history of the honey bee.

The exhibition was supported by three guest exhibitors : the Amateur Entomological Society, the School Nature Study Union and the Universities Federation for Animal Welfare. During the afternoon a colour film, "Coral Wonderland", was shown, describing life in and around the Great Barrier Reef of Australia. A catalogue of exhibits was available, and an enlarged edition of this catalogue, giving an account of the exhibition and a complete list of members, can be obtained from the honorary general secretary of the Association, O. N. Bishop, Kimbolton House, Kimbolton, Huntingdonshire, price 10d. post paid.

The general improvement in quality of presenta. tion, together with the maintenance of good scientific standards, are pleasing to note. Many of the exhibits were again on view in the Department of Zoology, University College, Leicester, on November 5, when the Association held its first provincial moeting. It is hoped thereby to encourage more Midland schools to take an active part in the work of the Association.

O. N. BISHOP

\section{DISSEMINATION OF SCIENTIFIC INFORMATION}

A CONFERENCE on the Dissemination of Science, organized by Unesco, was held in Madrid during October 19-22. Twenty-five delegates, representing national associations for the advancement of science and associations of science writers, took part. The United States and most European countries were represented, including Belgium, France, Denmark, Spain, Italy, Western Germany, Switzerland, Greece, Netherlands, Poland, Sweden, Turkey and Great Britain.

A wide range of problems was discussed on an agenda drawn up by the Unesco Secretariat, which agenda was severely criticized by many of the delegates because it failed to embrace the fundamental difficulties of scientific popularization. Nevertheless, many interesting issues were covered, and the widely different practices of the various countries soon became obvious.

Many of the delegates commented on the inaccuracy of scientific contributions appearing in the lay press and on the prevalent tendency of editorial staffs to make unauthorized changes in scientific articles. This particular problem does not exist to any great extent in Great Britain, where almost all papers of repute have a professional scientific correspondent. The position in France, however, appears to be so unsatis. factory that the French Association of Science Writers has devised a scheme which enables newspaper editors to check information rapidly on the telephone. The Association has prepared a chart giving the name and telephone number of scientists prepared to answer questions on given subjects at short notice. The usefulness of such a service is great ; but the Conference was at pains to point out that it should be regarded only as a temporary measure, and that the true solution lies in the recruit. ment by newspapers of adequately qualified scientific writers.
One of the documents prepared by the Drafting Committee under the chairmanship of Sir Bon Lockspeiser, a British delegate, stressed the importance of popularizing science and improving general scientific knowledge among certajn special sections of the community, embracing on one hand children and their parents, and legislators and business men on the other.

The future supply of scientists can undoubtedly be improved by awaking the children's interest in science at an early age. Even those who do not take up science will benefit from wider scientific knowledge than the present generation. It is important to interest parents also, for in many cases they will determine the career on which their children will embark. There was considerable discussion on the ways in which this group could be reached.

Mr. C. A. Reichen, of Lausanne, produced a number of copies of an excellent illustrated children's mage. zine, in which scientific matters were given considerable prominence. This magazine has the support of a number of industrial firms. It was considered desirable that similar publications should be started elsewhere. The need for more scientific programmes on radio and television for children was also discussed.

Prof. E. B. Schieldrop, of Norway, spoke on the value of laboratory visits, which had proved particularly successful in the University of Oslo. Sir Ben Lockspeiser strongly supported this point of view and said that the most valuable feature of such visits was that children and parents were able to see how scientists worked.

Mr. Watson Davis, director of 'Science Service', an American non-profit-making organization devoted to the popularization of science, told the Conference about the scientific clubs which have become popular among young people in the United States. From time to time these clubs organize science fairs-in effect conversaziones-in which all the exhibits are made and demonstrated by the members. These science fairs are well supported by local people.

It was considered that the best approach to the second group-those who control government or industrial policy-can be made through scientific articles written by scientists and science writers and published in the special journals read by the members of the group. A notable example of this technique is the regular publication of articles, on science and its application in industry, in the Financial Times. Such articles could help greatly in educating business executives in the possibilitios presented by the application of science.

Considerable interest was also shown in the paper prepared by Mr. M. Philips Price, M.P., on the Parliamentary and Scientific Committee. This informal group, which was started in the 1930's, now has considerable influence both in the House of Commons and House of Lords. It acts as a focal point where legislators may meet and discuss scientific, technical and related economic problems with men interested in research. In this way the influential layman may be kept informed of the part which science can play in public affairs.

The Conference agreed that such bodies play a most important part in furthering knowledge of science and that they should be established in other countries for legislators and possibly business executives also.

A considerable amount of time was spent in some. what futile discussion of science fiction and "the fight against false sciences". There was also much 
argument as to whether some form of international organization for co-ordinating the work of national associations for the advancement of science and the national associations of science writers should be set up. Finally, however, a recommendation was adopted to the effect that it was undesirable at the present moment to establish an international organization for these purposes, but that Unesco should consider the possibility of forming a consultative committee to further co-operation between the various national associations if this should prove necessary.

Although the Conference produced no definite or positive conclusions, it was nevertheless valuable in showing that the problems of popularizing science vary greatly from country to country, and in bringing people together with similar interests from many countries.

T. A. Margerison

\section{ROYAL BOTANIC GARDENS, KEW}

\begin{abstract}
A REVIEW of all aspects of the work of the Royal Botanic Gardens, Kew, during 1954, is presented in the Kew Bulletin, No. 1, 1955. The past year has been one of sustained progress, but various problems of accommodation remain acutefor example, the Palm House, the Herbarium and Library-and are receiving close attention. The main activities of the Gardens, however, are being maintained with unimpaired vigour. It is impossible to touch on more than a few of these in this short article, but some idea of the nature and volume of the problems handled may be indicated by some selected references. Thus, the specimens received for the Herbarium, excluding those prepared at Kew from living material, amounted to 55.994; some 9,166 sheets were received on loan; 5,652 were sent on loan; 16,424 sheets were distributed as duplicates; and, in all, some 47,780 sheets were mounted (excluding algae, lichens, fungi and bryophyta, and specimens received already mounted). No fewer than 4,077 botanists paid visits during 1954, many of these being from overseas, attending the Eighth International Botanical Congress at Paris. Here, too, reference may be made to the fact that 2,635 inquiries and plant consignments were dealt with during the year.
\end{abstract}

As in previous years, important activities were the identification of economic plant products and the supplying of information on economic plants: for example, cinnamon, groundnuts, sesamum, raffia, balsa, senna, sansevieria, capers, opium poppy, aloes, patchouli, pepper, ginger, vanilla and cardamoms. In relation to the present high prices of tea and coffee, various inquiries as to the possibility of growing these crops in new areas received consideration.

For many years the Gardens have rendered an important service to scientific agriculture by maintaining the Quarantine House, the function of which is to prevent the spread of diseases and pests during the transference of economic plants from one part of the world to another. Thus, at the present time, varieties of cacao from the Imperial College of Tropical Agriculture, Trinidad, have occupied most of the available space during the year, these being the most promising of the Imperial College selections of Trinidad trees and some Amazonian forasteros originally collected on the Upper Amazon. Rooted cuttings from these plants have been suitably packed and sent by air to the West African Cacao Research Institute, Gold Coast, and to the Departments of Agriculture in Malaya, Ceylon and Fiji, and, with the exception of a consignment sent to Malaya, are reported to be growing successfully in their new environments. Material of Theobroma and the related genus Herrania, collected in Colombia in 1952 and sent to Kew via Trinidad, is now on its way to West Africa for the use of plant-breeders there. Various banana and cotton collections are also under sur. veillance in the Quarantine House.

A further service to countries of the British Commonwealth consists in obtaining plants of potential value. For example, young plants of ipecacuanha (Cephaelis ipecacuanha Rich.) have been sent to the Departments of Agriculture in Nigeria, British Honduras and Malaya for local trials.

Work of a rather different kind consists of research on the systematic anatomy of the Monocotyledons; notes on this important and extensive undertaking have appeared from time to time in these columns. Arrangements for the publication of this work in three volumes, of which the first will deal with the Gramineae, have now been made with the Clarendon Press, Oxford. A large number of routine inquiries, relating to miscellaneous botanical materials, including timbers, archæological specimens, and rubbed and powdered herbs, have been dealt with in the Jodrell Laboratory during the year. Among the more unusual samples were nylon bobbins examined on behalf of the Board of Customs and Excise, twigs of alleged apple trees, most of which proved to be plum suckers, submitted by the laboratory at New Scotland Yard, and unsatisfactory pick handles which were found not to have been made of the timber that had been specified.

The report also deals in some detail with the progress that has been made in the preparation of the several regional floras, and with other taxonomic studies, and the cultural work in the different sections of the Gardens is appropriately reviewed. A comprehensive list of publications and a staff list conclude this interesting and important publication.

\section{OPINIONS AND SOCIAL PRESSURE}

W HAT is the effect of the opinions of others on our own? How strong is the urge towards social conformity? An American psychologist, Solomon E. Asch, has approached these questions by means of unusual experiments. These, and his findings, have been described in the November issue of Scientific American, which contains a number of other articles of outstanding interest as follows : "Trenches of the Pacific", by R. L. Fisher and R. Revelle; "Synthetic Diamonds", by P. W. Bridgman; "Radiation and Human Mutation", by H. J. Muller; "Empty" Space", by H. C. van de Hulst ; "What makes Leaves Fall ?", by W. P. Jacobs; "Etruscan Metallurgy", by A. N. Modora; "Too Many Deer", by A. S. Leopold*.

Dr. Asch's investigations were guided by certain underlying assumptions, which to-day are common currency and account for much that is thought and said about the operations of propaganda and public opinion. The assumptions are that people submit uncritically and painlessly to external manipulations by suggestion or prestige, and that any given idea or * Scientific American, 193 (November 1955), 2 West 45th Street, New York. 50 cents. 